\title{
The Primary Silence of the Past and the Weakness of Philosophy
}

\author{
KeITH WhitMoyer
}

There is little doubt that the concept of an "immemorial past" has become increasingly well recognized in contemporary philosophy, particularly in the wake of Levinas, Derrida, and Deleuze and a revived interest in Bergson. ${ }^{1}$ It is also clear that Merleau-Ponty finds himself uncomfortably in the midst of this cluster of thinkers: uncomfortable because his thought evinces a degree of ambivalence with regard to the immemorial past. For example, as Alia Al-Saji has suggested, Phenomenology of Perception's “emphasis on the field of presence of the lived body and on the primacy of perception, understood as givenness in the flesh," "seems to preclude such a concept of pastness irreducible to the present" (Al-Saji 42). Nonetheless, in spite of this otherwise seemingly transparent commitment to the primacy of the present in the earlier text, there is also the following well-known but curious remark: “... [R]eflection does not itself grasp its full sense unless it refers to the unreflective fund of experience which it presupposes, from which it profits, and which constitutes for it a kind of original past, a past which has never been a present" (Merleau-Ponty 1945/2006, 280/280, trans. modified). Phenomenology of Perception therefore seems to maintain a tension between Merleau-Ponty's commitment to Husserlian phenomenology and its apparent emphasis on the ontological primacy of the present, on one hand, and this curious and perhaps contradictory reference to the immemorial past on the other. Addressing this tension certainly poses difficulties and has become a focus for Merleau-Ponty 
scholars. ${ }^{2}$ One interpretation is that Merleau-Ponty was in the process of leaving the more traditional, phenomenological understanding of time behind (an understanding heavily under the influence of Husserl's Zeitbewusstsein) in favor of a conceptualization that emphasizes the Bergsonian ontological primacy of the past. This interpretation, then, can provide an index for tracking the "revision" that seemed to characterize the development of Merleau-Ponty's thought leading up to The Visible and the Invisible. On this basis, a case could also be made that his later works were moving toward a conceptualization of time perhaps closer to the thinkers mentioned, and we would have at our disposal the means for including Merleau-Ponty among thinkers for whom the immemorial past was a central concept.

In spite of its apparent plausibility there are two claims at play in this narrative that become problematic on closer inspection: first, that the development of Merleau-Ponty's oeuvre is characterized by a "revision," i.e., that The Visible and the Invisible amounts to a rejection or abandonment of the philosophical project outlined in Phenomenology of Perception; second (but correlatively), that the frameworks of the early and later works are transparently irreconcilablethat the ontology of the flesh proposed in The Visible and the Invisible replaces and thus excludes the more Husserlian, phenomenological approach characteristic of Phenomenology of Perception. ${ }^{3}$ Because Merleau-Ponty's interest in the immemorial past is often invoked in support of these claims, turning to his treatment of this concept will shed some light on these anxieties and the relationship between his earlier and later works. In light of Merleau-Ponty's curious reference to the immemorial past in Phenomenology of Perception, the idea that we could index the difference between the earlier and later works strictly through the concept of the immemorial past seems to be more of a problem rather than a solution. In addressing this tension, 
then, we should be cautious about availing ourselves of a significant revision in Merleau-Ponty's thought.

Rather than attempting to interpret the tension between the apparent primacy of the present and immemorial past within the framework of an ontological "turn" in Merleau-Ponty's work, this essay seeks to contextualize this reference to an immemorial past in 1945 . The most explicit discussion of time in Phenomenology of Perception, La temporalité, of course seems to be a reasonable place to begin. ${ }^{4}$ Looking at this chapter, however, we quickly see that the theme of donner sens or Sinngebung, sense-giving or bestowal, is central to the aims there, a theme, as it turns out, also prominent in the very chapter that contains his reference to an immemorial past, Le sentir. The tension between the immemorial past and the ontological primacy of the present becomes pronounced in light of Merleau-Ponty's account of sense-genesis as reprendre, resumption or taking up again, and his discussion of sense acquisition as articulated in the chapter, Le cogito. By elucidating Merleau-Ponty's account of sense-genesis in accordance with the functions of reprendre and acquisition in these places in the text, the first part of the essay elaborates the dual movement in which sense giving resumes the historical tradition of its accomplishments and the movement through which this tradition is simultaneously established. This account, however, underscores the primacy of the field of living presence as the originary field of genesis in Merleau-Ponty's theory of Sinngebung, a commitment that, as his closing thoughts in La temporalité indicate, suggests an ontology of ubiquitous sense in which what has not passed through the field of originary presence, an immemorial past, has no place. Given this account, then, it seems that the reference to the immemorial past in Le sentir could be little more than aberration or curiosity. 
Nonetheless, in a remark that attempts to situate the project of Phenomenology of Perception with respect to La structure du comportement, Merleau-Ponty sets his task, not as the articulation of the expressivity of being in its ubiquity, wholeness or plentitude, but precisely as thinking the passage between sense and non-sense. While this task seems to remain completely undeveloped in Phenomenology of Perception, the second part of the essay turns to "Indirect Language and the Voices of Silence" to further elaborate some indications for the significance of an original past in Phenomenology of Perception. In the context of this later text, as that which has not passed through the field of presence, the immemorial past names the perpetually silent écarts that make expressivity possible and bring it into a dynamic articulation. This silence is the field of non-presence, non-sense, and the mute fund on which the field of presence draws for its manifestation. The immemorial past, then, for Merleau-Ponty, names the withdrawal of sensethe a-sense - on which expression draws in its becoming and articulation. These reflections, finally, give some indication of the trajectory of Merleau-Ponty's thinking in The Visible and the Invisible. Rather than a "turn" or "revision," we see that the texts of the 1950s and then The Visible and the Invisible take up the project articulated already in 1945: thinking differential between non-sense and sense, between the mute indifference of the canvas and the painting, between the primary silence of the past and the eloquence of expression.

\section{The Ubiquity of Sense in Phenomenology of Perception}

As it is articulated in various episodes across Phenomenology of Perception, MerleauPonty insists on a theory of sense-genesis ${ }^{5}$ that understands this movement in terms of the reprendre ${ }^{6}$ the re-taking or resumption of a sense the articulation of which is already under way. In other words, sense-genesis is not to be understood as the positing activity of transcendental 
consciousness, as in Husserl, but as "re-constitution," the return to and resumption of a tradition of meanings for which explicit acts of positing or judgment arrive late (Merleau-Ponty $1945 / 2006,251 / 240)$. He insists on this point in order to directly challenge the idealist theory of sense-genesis, understood as "constitution,", which, as he later makes explicit in the 1954 lecture course, Institution in Personal and Public History, requires an active, positing consciousness as its necessary correlate. ${ }^{8}$ In this gesture, however, Merleau-Ponty also seems to insist on a certain ubiquity of sense: insofar as expression is understood as the resumption of instituted sense already under way, he seems to maintain an ontology in which being is understood as always already articulate, as always having and making sense in advance of those interpretive acts which take it up and resume it. Since there is no question of realism here, ${ }^{9}$ it is necessary to explicate this claim about sense-genesis as reprendre.

By insisting that sense-genesis takes the form of reprendre, Phenomenology of Perception anticipates the fundamentally historical, indeed, institutive structure of sense-genesis elaborated in the early lectures at the Collège de France as well as the critical attitude toward what he will designate as the "philosophy of consciousness" that figures in the working notes of The Visible and the Invisible. ${ }^{10}$ In other words, there seems to be a turn in the understanding of sense-genesis in Merleau-Ponty's thought from constitution to institution-from a philosophy of consciousness to a philosophy of history. Merleau-Ponty borrows this concept, Stiftung, from Husserl as a means for opening a space in which to raise a question that could be said to address both himself and Husserl as well. In the texts of the 1950s, Stiftung is translated as "institution," a conceptualization that will eventually be replaced by "initiation" in the years of The Visible and the Invisible. ${ }^{11}$ As he notes in a passage from "Indirect Language and the Voices of Silence," 
Husserl has used the fine word Stiftung - foundation or establishment - to designate first of all the unlimited fecundity of each present which, precisely because it is singular and passes, can never stop having been and thus being universally; but above all to designate the fecundity of the products of a culture which continue to have value after their appearance and which open a field of investigations in which they perpetually come to life again (Merleau-Ponty 1960/1964, 95/96).

By insisting that phenomenology abandon the language of constitution in favor of institution, Merleau-Ponty is reading Husserl against himself - that is, he is bringing the Husserl who remained committed to the project of transcendental idealism and retained the concept of constitution into dialogue with another Husserl whose thought opens onto something else. Sensegenesis is no longer a function of the intervention of a transcendental constituting consciousness but is the institution of a temporal dimension that will structure and articulate the sense that passes through it. In other words, sense bestowing and generating gestures take place within an already instituted historical framework that makes them possible. The idea of institution, however, was already outlined in Phenomenology of Perception in the concept of reprendre.

Reprendre initially becomes salient for sense-genesis in the discussion of the intentional structure of le sentir, sensing, in the chapter bearing this title. There, Merleau-Ponty claims that the sens, the meaning and orientation of sentir, ${ }^{12}$ is unintelligible if it is understood as the positing activity of transcendental consciousness. That is, the sens of sentir is not attributable to constitutive acts; rather, as he says, "is not constituted in full clarity, it is reconstituted or resumed $[\text { repris }]^{13}$ by a knowledge which remains latent, leaving it with its opacity and its ecceity [eccéité]" 14 (Merleau-Ponty 1945/2006, 258/248, trans. modified). The sens of the sensible is enveloped in a meaning that was already under way and which it resumes; it follows through, as it were, on "a certain rhythm of existence" (258/248). What Merleau-Ponty calls l'intentionnalité d'acte, ${ }^{15}$ our "thetic" or explicit intentional comportment, is late with respect to 
the sense of the sensible and, indeed, opens upon a world of "autochthonous significance" $(504 / 512) .{ }^{16}$ The sense of the perceived world is not miraculously brought into being through a spontaneous act of constitution, ex nihilo, but was already there - not as a ready-made and inherently significant fullness of sense without depth and without transcendence-but as the unfolding or becoming of sense, an adventure that does not refer to consciousness as its origin. The sensible, that which can be sensed because it has sense, thus emerges from the living dehiscence or deflagration ${ }^{17}$ of sense itself precisely in its ecceity-its plenary, factical thisness.

Merleau-Ponty's account of sense-genesis as reprendre, the resumption of this living deflagration, designates at least one way in which sense could be said to refer to an "unreflective fund" (280/282). As resumption, sense-genesis takes up this fund and carries it forward as articulation. This fund of sense, furthermore, has the temporal structure of "having been" and, understood in terms of resumption, sense-genesis makes reference to the past- to the history of meanings to which it returns and resumes. Is the past resumed, however, an immemorial past, a past that has never been present? To answer this question, we require an account of how the sense that is resumed, the historical tradition of instituted sense, itself originates - that is, an account of expression at its most archaic and originary level. The letter of Phenomenology of Perception requires us to accept what Merleau-Ponty calls le champ de présence as the field of origination, ${ }^{18}$ and if we situate this discussion of reprendre in the context of that of acquisition in Le cogito, which is central to the question of origination in this text, we get an account of the passage of sense from originary presence to the past, as sense-accomplishments are "driven into time like a wedge" (453/456). ${ }^{19}$ To this extent, this text seems to exhibit a commitment to the ontological primacy of the present in its account of the field of origination — an account in which the concept of an immemorial past seems to have no place. 
Merleau-Ponty's claim in Le cogito, following Husserl's account in The Origin of Geometry, is that cultural objects, including idealities such as the idea of a triangle, the quadratic equation, or Beethoven's Ninth Symphony, are possible thanks to the expressive power of acquisition and sedimentation, and it is precisely in virtue of this logic, as it is elaborated in these pages, that expression constitutes its own history, the fund of past accomplishments resumed in intentional acts. Expression, Merleau-Ponty says,

is to ensure, by the use of words already used, that the new intention resumes [reprend] the heritage of the past, it is at a stroke to incorporate the past into the present, and weld that present to a future, to open a whole temporal cycle in which the 'acquired' thought will remain present as a dimension, without our needing henceforth to summon it up or reproduce it" (453/456, trans. modified).

Indeed, "alone of all expressive processes, speech [parole] is capable of sedimenting and constituting an inter-subjective acquisition" (231/220, trans. modified). ${ }^{20}$ Expression incorporates the past into the present precisely in its function of reprendre, resumption and reopening. In this function, however, what is expressed simultaneously takes its place in this tradition and history - that is, takes its place in the past of an accomplished sense that becomes sedimented. Such acquisition is possible thanks to temporality's retentive function, ${ }^{21}$ because each moment of time succeeds another and passes into the past, and what is accomplished and acquired in this passage attains its "inalienable place" in the tradition. Indeed, "[e]ach moment of time, in virtue of its very essence, posits an existence against which the other moments are powerless" (453/456). Acquisition, then, as well as the history and tradition of acquired meanings that result from it, is nothing other than the passage of an expressive act from the field of originary presence into the sedimented and retained past.

Given Merleau-Ponty's account of expression as reprendre and its function of acquisition, it seems that the fund of past experience which expression resumes is hardly a past 
which has never been present but the fund of acquired meanings that have been driven into the past from their genesis in originary presence. Rather than an immemorial past, the past of that which remains irreducible to the field of presence, we have a past which is nothing other than the stock and tradition of meanings acquired in expressive acts - the memorial past of presence. This past is that of a ubiquity of sense, the past of all that has been said and that has passed from its moment of articulation in the field of presence into the sedimented history and tradition that is retained and then resumed in expressive acts. Rather than an original past, we have a cyclical past, constituted in the field of presence and taken up again in expression.

Sense-genesis, expression, thus resumes a sense already under way and in so doing contributes to the fund of sense, which is again resumed. It is perhaps unsurprising, then, that Merleau-Ponty also describes sense-genesis in terms of reprise, recovery or repetition. ${ }^{22}$ As he notes in Le sentir, because each act of perceptual synthesis is characterized by its dissolution, "the pretention to objectivity of each perceptual act is recovered [reprise] by its successor, again disappointed [déçue] and again recovered [reprise]" (287/278, trans. modified). Sense becomes articulate, not ex nihilo, but in the very reference it makes back to the history and tradition of acquired meanings - a history that it precisely recovers, resumes and carries forward into the future. The expressive act, for Merleau-Ponty, is also the repetition of already acquired meanings - a reiterative process that sediments and reifies the tradition of sense resumed. The result, however, is a certain self-referentiality of this tradition and history - a self-reference, it seems, that the expressive act cannot transcend or escape. It seems that we can conclude from this account, then, that as beings open to sense, we are always already immersed in the richness and fecundity of the sensible. As Merleau-Ponty will note at the end of Phenomenology of Perception in La liberté, "We are always in the fullness, in being, like a face, even in rest, even 
dead, is always condemned to express something (there is, in the dead, surprise, peace, discretion), like silence is still a modality of the sonorous world" (516/525, trans. modified) and in the Preface, "Because we are in the world we are condemned to sense" (20/xxii, emphasis Merleau-Ponty's) ${ }^{23}$ It seems that we cannot escape the historical and institutive structure of sense in which we always find ourselves immersed. According to Merleau-Ponty's account, we are condemned to the ubiquity of sense, which we find everywhere.

This account has not yet brought us back to the origin of sense-the differentiation of sense from non-sense-since we never get beneath a certain solipsism of sense but are perpetually immersed in and condemned to this self-referential sensical and sensible order. Merleau-Ponty describes this ontology in a working note from The Visible and the Invisible: ${ }^{24}$ Intentional analysis, accordingly, gives us the following with respect to the past: "[E]very past sinngemäss has been present, i.e., its past being has been founded in a presence_-And, certainly, that is so true [of ?] it that it is still present" (Merleau-Ponty 1964/1969, 292/243-44). If we remain within the confines of the method of the intentional analytic, as Phenomenology of Perception presumably did, then the past is the past of presence, we remain within the ontology of sense, and the immemorial past remains unthinkable. As he goes on to remark in the same working note:

But precisely there is here something that the intentional analytic cannot grasp, for it cannot rise (Husserl) to this 'simultaneity' which is meta-intentional.... The intentional analytic tacitly assumes a place of absolute contemplation from which the intentional explicitation is made, and which could embrace present, past, and even openness toward the future- It is the order of the 'consciousness' of significations, and in this order there is no past-present 'simultaneity,' there is the evidence of their divergence [écart] (292/243-44).

Another way to state Merleau-Ponty's complaint, which he will repeat in other working notes, is that the intentional analytic remains committed to and thus in the confines of the 
philosophy of consciousness. ${ }^{25}$ In conceptualizing the past, Husserl's method attempts to take up the position of what Merleau-Ponty calls the survol absolu—an impossible perspective of absolute surveillance that would be capable of explicating the intentionalities that structure time's passage by embracing its dimensions: past, present and future. The intentional analytic is only capable of this embrace, however, by restricting itself to the order of the noema and the noemata - the consciousness that intends and the significations that become the object of this intention. This order, because it enumerates temporal passage according to the series of intentionalities in retentions and protentions, is therefore incapable of conceptualizing the simultaneity of past and present—it cannot think the immemorial past, the mythical weight of the past in our present experience, the weight of the hawthorns that crush down upon Proust's protagonist. Conceptualizing such simultaneity requires reference to a past beyond presence, memory, and history, "to the time before time, to the prior life, 'farther than India and China"" $(292 / 243-44)$.

While such a remark seems to unequivocally indicate a critical stance toward the project of Phenomenology of Perception to the extent that it was committed to the method of intentional analysis, the position of the earlier text was far from categorical. What is at stake is the possibility of thinking this "time before time:" the primordial differentiation of sense from nonsense, that which lies beneath the solipsistic order of acquisition, sedimentation and reactivation. Conceptualizing such a threshold, however, was already on the horizon of Merleau-Ponty's thought in Phenomenology of Perception. As he says in Le corps comme expression et parole, "Our view of man will remain superficial so long as we fail to go back to that origin, so long as we fail to find, beneath the noise of words [bruit des paroles], the primordial silence, as long as we do not describe the gesture [geste] that breaks this silence" (Merleau-Ponty 1945/2006, 
214/184, trans. modified). What is necessary, accordingly, is to interrogate the differential between sense in its resumptive, recovering logic of articulation and the point at which it is born-the point at which, to borrow an image from Merleau-Ponty, an inarticulate scream becomes a spoken word; the point at which the blank canvas or blur of colors becomes the painted figure and ground; indeed, the point at which a certain primordial silence - the absence of sense, non-sense-is broken and transmuted into visibility and articulation. ${ }^{26}$ While Phenomenology of Perception already opens upon this possibility, it nonetheless never seems to think through this "primordial silence" in any detail. There are, however, other important remarks in La temporalité that may clarify the significance of this primary silence, a concept that would be taken up in detail in the work of the years following. We may make some suggestions as to the significance of primordial silence in relation to the immemorial past by turning to $L a$ temporalité and a text from the 1950s.

\section{The Original Past and Primary Silence}

While it remains undeveloped in Phenomenology of Perception, Merleau-Ponty's reference to the immemorial past at the end of Le sentir suggests that there must be another understanding of the past implicitly at play in the pages of this text beyond the past of presence. If the past of presence is the fund of acquired experience and sense, that which has been brought into articulation through resumptive and recovering acts of expression, then it seems to follow that the immemorial past is irreducible to what has been expressed, what we could perhaps call the "sensical past," the past of the history and tradition of what has been expressed. If this is the case, however, then we can describe this immemorial past only in terms of that which was never present within the domain of the instituted history and tradition - that which is beyond the limits 
of sense, beyond the limits of the sensible, speech and memory. This other domain, precisely as a past which has never been present, as that which has no place within the order of sense, could aptly be designated as the domain of non-sense- that which is constitutively unexpressed and inexpressible, indeed, what Merleau-Ponty had already called "primordial silence." 27 Though such an account is never developed in any detail in the pages of Phenomenology of Perception, it seems that the primacy of such a past would lie in the manner in which, beneath the institutional order or sense, this silence is nonetheless the empty referent of expressivity and that therefore the order of sense is, as Leonard Lawlor puts it, like "a repetition without original" (25).

If our task is now to elaborate an account of this perhaps marginal or implicit relationship between primary silence and expression, non-sense and sense, then a remark made at the end of La temporalité may prove instructive. Merleau-Ponty summarizes the task of his earlier work, $L a$ structure du comportement, which was understood to be the elaboration of the exchange between consciousness and nature, the inner and the outer. Phenomenology of Perception presumably takes a step beyond the first book to the extent that it is no longer bound to this dualistic ontological framework. As he says it was articulated elsewhere, Merleau-Ponty sees his philosophical task in terms of "understanding what, in our world and in ourselves, is the relation between sense and non-sense" (Merleau-Ponty 1945/2006, 490/497, trans. modified, MerleauPonty's emphasis). To put it differently, the task of Phenomenology of Perception, as stated here, is to elaborate the passage between the primary silence beneath sense and the moment of originary expression, the emergence of the institution, the first word, from the original anarchy and dissonance of an inarticulate scream. Of course, Husserl and other idealists have understood this passage to be established in the intervention of an active, constituting consciousness. Sense, for idealists, is understood as the product or result of "centrifugal," legislating processes of 
construction [construire], constitution [constituer] and synthesis [synthèse] (492/497). The analyses of perception and the body, however, have "revealed a more profound significance" for the genesis of sense (492/497). As we have already seen, for Merleau-Ponty in this text, we no longer have a theory of sense-genesis understood as the centrifugal activity of constituting consciousness but as the reprendre of sense always already under way, understood referencing Heidegger of course as "ek-stase." ${ }^{28}$ The idealist's understanding of sense-genesis is thus understood to be "secondary and derivative in relation to that pregnancy of signification within signs which could define the world" $(492 / 497) .{ }^{29}$ Sense is no longer understood to refer to constituting consciousness as its origin, its cradle or dwelling, as he says, but to the world itself, and thus Phenomenology of Perception can claim to have disclosed a "a new sense of the word 'sense"” (172/170).

The discussion of this new concept of sense at the end of La temporalité concludes with a series of claims about time's significance for what Merleau-Ponty calls "presence" [présence]. The arc of this claim, which I will only outline briefly, is that what he has designated by this new sense of sense is nothing other than temporality. Temporality, in turn, is the basic principle of presence, more accurately understood in terms of manifestation or appearance than as a temporal dimension. ${ }^{30}$ If temporality is the principle of the sense of sense, the phenomenality of phenomenality, it is, then, through time that "one thinks being" [qu'on pense l'être] (492/430). Time is the principle of the deflagration of sense, the sense of life, ${ }^{31}$ and as such, it discloses what were heretofore designated by subject and world as abstract moments of a single phenomenon called "presence." To put it somewhat differently, we could say that time is the principle of articulation ${ }^{32}$ through which sense itself becomes, and "presence," in this context, 
designates nothing other than this process, unfolding or becoming, indeed, this temporal déhiscence of the sense of being.

Insofar as presence designates the being of temporality (and the temporality of being), we find ourselves not (only) at the threshold of a new understanding of transcendental consciousness, which "already finds itself at work in the world," but of nature as well. Indeed, "What is true in total is that there is a nature, not that of the natural sciences but that which perception shows [montre] me" (432/494). Consciousness and nature, the inner and the outer, even time and space, no longer stand in an oppositional relationship: consciousness no longer soars over nature as survol absolu, for it is nothing other than the temporal expressivity of nature in its dehiscence. Nature, likewise, is no longer the dead object dissected and desiccated by the analyses of the natural sciences but is the vital horizon of my experience. Nature is that sensuous fecundity in which one is immersed, the vast richness of meaning to which one is condemned and that gives voice to itself in and through time. My voice is only something like the echo of the voice of nature, which speaks through me, and indeed, those words are only ever its resumption and repetition. $^{33}$

This account, however, still does not take us beyond the ubiquity of sense. In fact, what we have are the makings of an "ontology of sense," where being is understood as this temporal, expressive dehiscence - understood in its identity with presence, that is, with articulation and appearance: in other words, phenomenality itself. ${ }^{34}$ This is not to say that sense is a being among beings - it is, rather, the event or advent of being in its becoming, in its expressivity. Does the immemorial past, which has been identified with primary silence, non-sense, have a place in this ontology? If it is the case that what we have is an ontology of sense, if we are indeed condemned to sense and expression, then it seems that answer must be no. Nonetheless, if we accept this 
conclusion, then the remark about the immemorial past at the end of Le sentir is again merely a curiosity or aberration. ${ }^{35}$

Nonetheless, Merleau-Ponty's remark about his intention to disclose the relationship between sense and non-sense in this text may provide a point of departure for elaborating a thought that remains only marginally articulated in the pages of Phenomenology of Perception. The task set forth in this remark was accounting for the differential or divergence of sense and non-sense in terms otherwise than the intervention of a constituting consciousness. The question, then, is what is the principle of this differential? Indeed, if sense is no longer understood as the result of the positing activity of consciousness but, as it were, as the auto-phenomenality of being in its temporal déhiscence, then it seems we can no longer appeal to transcendental consciousness as the principle of this difference. What, then, establishes the sense of the difference between sense and non-sense, the sense of the non-phenomenal, that which was never present, in its difference from the field of presence, that is, the difference between primordial silence and expressivity? At what point does the inarticulate scream become the spoken word?

It seems to be this kind of question that motivates Merleau-Ponty's interest in the phenomenon expression in the years following the publication of Phenomenology of Perception, ${ }^{36}$ and turning to the writings of this period would provide some insights for elaborating the account of primary silence that remains only fragmentary and marginal in the earlier work. To briefly provide some indications, this differential seems to be what is at stake in "Indirect Language and the Voices of Silence" in the discussion of a slow-motion film made of Matisse painting, of this gesture that breaks the primordial silence. ${ }^{37}$ This film and the hesitation of Matisse's brush before plunging onto the canvas make this differential visible, and what we see is nothing other than the moment in which sense comes into being or is born from the midst 
of a certain kind of non-sense - the undifferentiated blankness of the canvass. What is visible is the metamorphosis of silence into expression, of the invisible into the visible. It is no different for all primordial acts of expression, accordingly, and the task of this essay is, as Merleau-Ponty says "to consider the word before it is spoken, the background [fond] of silence which does not cease to surround it and without which it would say nothing, or to put the matter another way, we must uncover the threads of silence with which speech is intertwined" (Merleau-Ponty 1960/1964, 58/83-84). While Merleau-Ponty still acknowledges the manner in which expression takes the form of the reprendre of an already constituted sense in this text, the task is now to more explicitly elaborate the primary expression that inaugurates or initiates ${ }^{38}$ this resumption against the background of primary silence. Disclosing this order requires a phenomenological reduction capable, he says, of "shaking up the linguistic apparatus and tearing a new sound from it" and of seeing language itself as a "mute art" akin to painting (58/84).

By taking up these suggestions, we can enumerate a series of clues for understanding the significance of the immemorial past in Phenomenology of Perception and Merleau-Ponty's philosophy more generally. As the past of primary silence, such a past would designate original non-phenomenality, the divergences or écarts of original silence, of a primordial non-sense without which sense would not be possible, and the artist, indeed, "all who transform in speech a certain silence" (Merleau-Ponty 1945/2006, 214/450, trans. modified) seems to have a privileged role in the reduction that discloses this silence, this past which was never present, and its differentiation from sense. The immemorial past, "primary silence" understood as that which is without articulation, beyond articulation, beyond memory, is a designation we could give to this non-sense. The past that has never been present, then, refers to an originary temporal dimension without which time's passage would remain unintelligible, ${ }^{39}$ a pure past in the Bergsonian sense: 
that which, precisely as past, remains absent, concealed and inarticulate, that which remains constitutively silent in the dehiscence of sense. Such non-sense would be the primary silence of becoming, its a-sense, if you will, and it is in the perpetual withdrawal and self-concealing of this silence that sense establishes itself and in which speech becomes possible.

As even a brief survey of how silence figures in The Visible and the Invisible bears out, it seems that Merleau-Ponty never ceased being concerned with establishing the principle of the differential between non-sense and sense, between primary silence and articulation. In one of his favorite passages from Husserl, oft quoted, he says that philosophy "is the experience... still mute which we are concerned with leading to the pure expression of its own meaning;" in other words, philosophical interrogation involves "the reconversion of silence and speech into one another" (Merleau-Ponty 1964/1968, 169/129). And yet the task of elucidating this conversion, this differential, of interrogating the metamorphosis of silence into speech, appears to be an infinite one. A passage from The Visible and the Invisible provides an indication of how Merleau-Ponty was thinking about this passage and differential—-this threshold—at the end of his life. The passage is from Interrogation et intuition:

The philosopher speaks, but this is a weakness in him, and an inexplicable weakness: he should keep silent [se taire], coincide in silence, and rejoin in Being a philosophy that is there ready-made. But yet everything comes to pass as though he wished to put into words a certain silence he hearkens to [écoute] within himself. His entire 'work' is this absurd effort. He wrote in order to state his contact with Being; he did not state it, and could not state it, since it is silence. Then he recommences... (164/125).

The philosopher stands at the threshold between non-sense and sense, wishing to transmute, like an alchemist, that silence into speech - to make sense of the non-sense, to listen and bear witness to the silent, inarticulate scream of being and translate it into words. To accomplish this transmutation, the philosopher foolishly speaks, as if silence could be figured 
only in sound, as if this non-sense hides a secret logic. It is speech, expression - writing - that, for Merleau-Ponty, is the philosopher's foolishness, madness and weakness as this absurd enterprise - making silence speak — was destined to fail from the beginning. In the face of this failure, philosophy must perpetually recommence.

These remarks come very close to the vision of the philosophical enterprise already outlined in Phenomenology of Perception. If philosophical interrogation is the task of bringing this primordial silence into expression, then it seems that it is indeed fated to remain "like a repeated disappointment and failure" (Merleau-Ponty 1945/2006, 517/526, trans. modified). Philosophy, as an experience of failure, is also nothing other than "a renewed experience of its own beginning [commencement]" which "consists wholly in the description of this beginning" (14/xv-xvi, trans. modified). The philosopher, for her part, the initiator of this perpetual failure, is thus also nothing other than "a perpetual beginner [commençant]." This seems to be one of the important lessons of the philosopher's weakness for expression-this task will never succeed, but the experience of this failure does not result in a resentment that would keep its frustrated gaze fixed on the final recovery of truth and being. The task of disclosing the differential of sense and non-sense, the birth of expression from this primary silence, giving voice to becoming, for Merleau-Ponty, is not a matter of coincidence or finalization. It is the infinite task of trying to speak what was otherwise unspeakable, to express what was otherwise thought to be impossible, a task that cannot be exhausted and must be perpetually renewed, resumed and reprised, and in this way philosophy becomes an infinite meditation on the possibility of its own beginning. 


\section{Notes}

${ }^{1}$ Levinas, of course, makes use of this concept in "Ethics as First Philosophy," where he famously notes that "Responsibility for my neighbor dates from before my freedom in an immemorial past, an unrepresentable past that was never present and is more ancient than consciousness of..." (Levinas, 84). This concept also carries weight in Joanna Hodge's reading of Derrida, whom she sees him borrowing heavily from Levinas. See Hodge, 102. Deleuze will prefer to talk about the "pure past," a concept that he borrows from Bergson. See, for example, Deleuze 1968/1994, specifically the discussion of time in the second chapter, and Bergson, 1911/1988. See also Deleuze, 1966/2006.

${ }^{2}$ While this list certainly does not exhaust the work done on this topic, notable recent contributors include Al-Saji, Alia, 2008; Lawlor, Leondard, 1998; and Dillon, Martin, 1993.

${ }^{3}$ Barbaras has proposed this reading. See Barbaras, Renaud, 2000, 2004, 2009.

${ }^{4}$ Dillon has suggested that we understand this remark in the context of Le sentir in terms of the reflective and pre-reflective. Lawlor, however, citing the centrality of the theme of temporality for Phenomenology of Perception as a whole, suggests that we must turn to La temporalité. AlSaji also takes us to La temporalité and Merleau-Ponty's discussion of Husserl's Zeitbewusstsein for adjudicating this question. While I tend to agree with Lawlor and Al-Saji's suggestion of $L a$ temporalité, we need not choose between one discussion or another if we bring the theme of sense-genesis to bear on the question of the originary past since it is central in both chapters.

${ }^{5}$ There is no one chapter that deals with this question exclusively. Rather, the question of sensegenesis is a theme of meditation to which the analyses of this text constantly return. Its perhaps most compelling treatments occur in Le corps comme expressions et la parole, Le sentir, and La temporalité.

${ }^{6}$ It's worth noting the fluid significance of this term in French. While it literally means to "retake," "resume" is probably a more standard translation. It can, however, also mean to "re-open," "return" and "restart," all of which prove interesting in the context of a theory of sense-genesis. Merleau-Ponty chooses this term in particular to emphasize, as has been acknowledged by commentators, cf. Al-Saji 2008, Lawlor 1998, the dependence on or reference that thetic or active expression makes to the ground of a sense always already under way.

${ }^{7}$ In fact, he even goes so far as to say in Phenomenology of Perception that "I am not a constituting thought," (Merleau-Ponty 1945/2006, 437/434) and that subjectivity "does not constitute the world, it divines the world's presence round about it as a field not provided by itself; nor does it constitute the word, but speaks as we sing when we are happy; nor again the sens of the word, which instantaneously emerges for it in its dealing with the world and other men living in it..." (470/465).

${ }^{8}$ In this lecture, Merleau-Ponty remarks that "In the concept of institution we are seeking a solution to the difficulties found in the philosophy of consciousness. Over and against 
consciousness, there are only the objects constituted by consciousness. Even if we grant that certain of the objects are 'never completely' constituted (Husserl), they are at each moment the exact reflection of the acts and powers of consciousness." Furthermore, institution "makes no sense for consciousness or, what amounts to the same thing, everything for consciousness is instituted in the sense of being posited... To constitute in this sense is nearly the opposite of to institute: the instituted makes sense without me, the constituted makes sense only for me and for the 'me' of this instant... The instituted straddles its future, has its future, its temporality, the constituted depends entirely on the 'me' who constitutes (the body, the clock)" (Merelau-Ponty 2010, 76, 8).

${ }^{9}$ Merleau-Ponty's unequivocal opposition to realism in the context of Phenomenology of Perception is clear as he says, "there is no question of [its] justification" (Merleau-Ponty 1945/2006, ix/9, 430/427).

${ }^{10}$ The Institution lecture from 1954-55 already mentioned as well as Le monde sensible et le monde de l'expression from 1953. In both texts, the concept of consciousness and its significance for the project of phenomenology comes under close scrutiny. In a working note of The Visible and the Invisible dated January 1959, Merleau-Ponty remarks that what he had called the tacit cogito in Phenomenology of Perception is "impossible." See Merleau-Ponty 1964/1968, $171 / 222$. Merleau-Ponty repeats this thought in another note dated February 1959, entitled "Tacit Cogito and Speaking Subject" (227/175). In yet another note, also dated February 1959, Merleau-Ponty writes: "Results of Ph.P._ - Necessity of bringing them to ontological explication" and that the "problems that remain after this first description: they are due to the fact that in part I retained the philosophy of "consciousness" (234/183). Later in the text he notes that the problems posed in Phenomenology are "insoluble because I retained the consciousnessobject distinction----" (250/200).

${ }^{11}$ On initiation, see note xxxvii.

12 As is well known, sens means both "sense" and "direction." I've chosen the word "orientation" here to underscore the fluidity that exists between these two significations, a fluidity inevitably lost when translating it into English. Sentir, typically translated as "feeling" or "sensing," is the verbal form of sens. Sentir, then, literally means "to sens," to be a being for whom an openness and genius for sens is its essential possibility, a significant and signifying being. As Merleau-Ponty argues in the Introduction to Phenomenology of Perception, this originary sense of sentir has been forgotten by traditional accounts of perceptual experience insofar as they reduce sentir to sensation (61/64-65).

${ }^{13}$ As in the passé simple of reprendre.

14 Eccéité could also be translated as "haecceity," from mediaeval philosophy, meaning "thisness." Of course this is also an important term for Deleuze. As he notes with Guattari in note in A Thousand Plateaus: "This is sometimes written 'ecceity,' deriving the word from ecce, 'here is.' This is an error, since Duns Scotus created the word and the concept from haec, 'this 
thing.' But it is a fruitful error because it suggests a mode of individuation that is distinct from that of a thing or a subject" (Deleuze and Guattari 1987, 540). Deleuze and Guattari's remark is useful since it suggests a manner of understanding Merleau-Ponty's use of this term that is reducible neither to realism nor idealism.

15 The distinction between l'intentionalité d'acte and l'intentionalité operante occurs in MerleauPonty 1945/2006, 18/xx, 480/486.

${ }^{16}$ Dillon addresses what he describes as "the principle of autochthonous organization" in the "Ontological Implications of Gestalt Theory" chapter of his book, Merleau-Ponty's Ontology. This thesis, according to Dillon, following the Gestalt psychologists, is directed against the constancy hypothesis of traditional empirical accounts of perceptual experience. As Dillon defines it, "According to the principle of autochthonous significance, the perceptual world is intrinsically meaningful." It asserts that "culture, history, language and other human meaning structures... are founded upon a primordial level of meaning which is intrinsic to perception at its most fundamental level" (Dillon 1988, 66). An important ambiguity remains problematic in Dillon's account, however, insofar as he insists on describing perception as "intrinsically" meaningful, an ambiguity that indeed stems from Merleau-Ponty's own use of the term "autochthonous" [autochtone]. One could construe such remarks as tacitly committed to the claim that the perceptual world is meaningful in itself, that is, committed to a certain form of realism. Neither Dillon nor Merleau-Ponty would agree with such an interpretation since this would indeed re-inscribe the account within the dialectic of the in-itself and the for-itself, thing and consciousness. Rather, we must understand the sense of the autochthonous significance of perceptual experience as a sense that is not ready-made or inherent but as a sense that is in transit and in process, a sense in becoming, a sense to which reason and discourse have, as it were, only arrived after the fact.

${ }^{17}$ This is a term Merleau-Ponty uses in "Eye and Mind." See Merleau-Ponty 2007, 140.

${ }^{18}$ As has been observed by Al-Saji. See above.

${ }^{19}$ Merleau-Ponty turns to the phenomenon of expression in Le cogito in the section entitled "L'idée et la parole, l'exprimé dans l'expression." In a working note of The Visible and the Invisible, Merleau-Ponty remarks that: "The tacit cogito, of course, does not solve these problems. In disclosing it as I did in PhP, I did not arrive at a solution (my chapter on the Cogito is not connected with the chapter on speech): on the contrary, I posed a problem. The tacit Cogito should make understood how language is not impossible, but cannot make understood how it is possible-There remains the problem of the passage from perceptual meaning to the language meaning, from behavior to thematization" (Merleau-Ponty 1964/1968, 227/175-76).

${ }^{20}$ It is interesting and worth noting here that, in what appears to be a direct reference to The Origin of Geometry, Merleau-Ponty cites speech as the model for the acquisition of ideality rather than writing. This, as would prove so crucial for Derrida's reading of this text and subsequent work, goes against the letter of what Husserl himself says there. Merleau-Ponty's 
following remark addresses Husserl (and Derrida) directly: "This fact cannot be explained by pointing out that speech can be recorded on paper, whereas gestures or forms of behavior are transmitted only by direct imitation" (231/220).

${ }^{21}$ As is well known, Merleau-Ponty's discussion of le champ de présence in La temporalité follows Husserl's discussion of the Zeitbewusstsein quite closely. See Merleau-Ponty 1945/2006, 475/483ff.

${ }^{22}$ In Le sentir, Merleau-Ponty describes sensation as the "recovery [reprise] by the sentient subject of a form of existence identified by the sensible" (Merleau-Ponty 1945/2006, 255/257); that it is through time that there is a "nesting [emboitement] and recovery [reprise] of earlier in subsequent experiences" (278/279); that certainty is the "recovery [reprise] of a tradition of thought which cannot be condensed into evident truth without renouncing explication" (454/461); indeed, "there is sense for us when our intentions are fulfilled, or inversely, when a multiplicity of facts or signs are ready on our part for a recovery [reprise] which comprehends them, or in any case, when one or more terms exist as... representative or expressive of something other than themselves" (490/498).

${ }^{23}$ This remark is clearly an allusion to and play on Sartre's claim in L'etre et le néant: "In short the For-itself is free, and its Freedom is to itself its own limit. To be free is to be condemned to be free." See Sartre, Jean-Paul, 174/129.

24 The working note is dated April 1960 and titled "'Indestructible' past, and intentional analytic-and ontology."

25 The explicit criticisms of Phenomenology of Perception found in the working notes of The Visible and Invisible, which are cited in defense of a "revision" and "ontological turn" in Merleau-Ponty's thought, are found in some working notes dated from 1959. See above, note 10.

${ }^{26}$ Of course, after Phenomenology of Perception, the figure of the artist plays an increasingly prominent role in thinking through the problem of genesis. As Merleau-Ponty famously notes in "Cezanne's Doubt," "Because he returned to grasp consciousness at the mute and solitary fund [fond] of experience on which culture and the exchange of ideas are built, the artist launches his work as a man has launched the first word, without knowing if it will be anything other than a scream." See Merleau-Ponty, 1996/1964, 24-25/40, trans. modified.

${ }^{27}$ We must be careful not to conflate the conception of non-sense as primary silence with the absurd. Merleau-Ponty was no skeptic, and his position is that the demand for apodictic certainty that has guided most of the history of philosophy is tantamount to radical skepticism or what he calls a philosophy of the absurd. Between apodictic certainty and absurdity, accordingly, is the domain of opacity and ambiguity and it is this domain, accordingly, that a phenomenology of perception interrogates. See Merleau-Ponty 1945/2006, 342/345. 
${ }^{28}$ This is one of several references to Sein und Zeit in La temporalité-references too often overlooked by commentators. See Merleau-Ponty 1945/2006, 492/497. In Being and Time, Heidegger remarks: "The future, the character of having been, and the Present, show the phenomenal characteristics of the 'towards-oneself', the 'back-to', and the 'letting-oneself-beencountered-by'. The phenomena of the 'towards...', the 'to...', and the 'alongside...', make

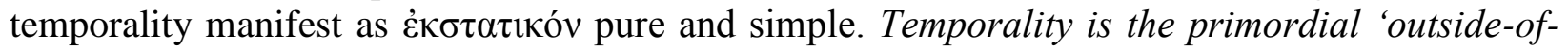
itself' in and for itself. See Heidegger, Martin, 1927/1962, 329/377. It's worth noting that in the passage where Merleau-Ponty references $e k$-stase, he specifically criticizes the idea that this "dispersion" could be overcome in authenticity. For Merleau-Ponty, once we recognize the ekstatic structure of temporality, we're committed to a temporal dissolution that no form of anticipatory resoluteness could outstrip.

${ }^{29}$ At this point, Merleau-Ponty returns to his distinction between l'intentionalité d'acte and l'intentionalité operante. While Merleau-Ponty explicitly attributes this distinction to Husserl $(\mathrm{xx} / 18,486 / 480)$, in the texts cited (Zeitbewusstsein, 79-80/430 and Formale und Transzendentale Logik, 235/208), Husserl never actually uses the exact phrase fungierende Intentionalität. Indeed, Husserl speaks of a lebendige Intentionalität, a living intentionality, that as lebendig fungierende, living operatively, may be unthematisch, non-thematic. In the same footnote, Merleau-Ponty cites Fink as well, Das Problem der Phänomenologie Edmund Husserls, 286. Operative intentionality, as Merleau-Ponty adds upon mentioning this concept in La temporalité, "is what Heidegger terms transcendence" (Merleau-Ponty 1945/2006, 486/480).

${ }^{30}$ Merleau-Ponty's discussion of le champ de présence in La temporalité should not be taken to betray a commitment to the ontological primacy of the present. Merleau-Ponty's aim in this discussion, rather, is to think the field of presence as a field of temporal passage in which there is no absolute presence in a twofold sense: no temporal present which is not already the passage between past and future and simultaneously no presentation that is not already its temporal "disarticulation" [désarticulation].

31 "Il est à la lettre le sens de notre vie" (Merleau-Ponty 1945, 492). This remark probably quite intentionally echoes a passage from Claudel that figures as one of two epitaphs for $L a$ temporalité: "Le temps est le sens de la vie (sens : comme on dit le sens d'un cours d'eau, le sens d'une phrase, le sens d'un étoffe, le sens de l'odorat)" (410/469). The passage is from Art poétique. The other epitaph, perhaps not incidentally in this context, is from Sein und Zeit: "Der Sinn des Daseins ist die Zeitlichkeit." See Heidegger, Sein und Zeit, 331.

${ }^{32}$ Which, for Merleau-Ponty, is simultaneously a principle of "disintegration" [disintegration] and "eruption" [éclatement], indeed, what he describes as the total déhiscence of time in its manifestation. See Merleau-Ponty's discussion in La temporalité (Merleau-Ponty 1945/2006, 487/481).

${ }^{33}$ This seems to be what Merleau-Ponty has in mind when he says in "Cezanne's Doubt," "The landscape thinks itself in me, and I am its consciousness" (Merleau-Ponty 1964/1996, 24-25/40). 
${ }^{34}$ For an account of this ontology and the significance of nature, see Toadvine 2004. Using the word "ontology" here may give the impression that Merleau-Ponty collapses or ignores the ontological difference. As Toadvine points out, however, this is not the case: "The claim that sense is ontologically fundamental, then, must be qualified, since this may give the impression that sense is something present, a being. But sense is rather a happening, the event of radical creation, a vortex of self-reflective movement whose ongoing rupture throws off questioner and questioned, subject and object, body and thing, as so many by-products of its fission" (Toadvine 2004).

${ }^{35}$ As Al-Saji (2008) states: "The picture of time in the chapter on 'Temporality...' is one that closely follows Husserl's theory in his lectures On the Phenomenology of the Consciousness of Internal Time, centering on the primordiality of the living present. The idea of an 'original past,' a past that does not derive from retention of a former present, seems to have no place in the conceptual map of the Phenomenology of Perception" (2).

${ }^{36}$ As Lefort indicates in the Preface to Prose of the World, based on the works published in Sense and Nonsense and the themes of the courses offered at the Collège de France throughout the 1950s, it seems that the problem of expression never ceased to compel Merleau-Ponty in the years after Phenomenology of Perception, leading up to the publication of "Indirect Language and the Voices of Silence" in 1959. See Merleau-Ponty, Maurice, 1981, xviii.

${ }^{37}$ This discussion is retained from The Prose of the World, as it appears both there (MerleauPonty 1981, 44 ff.) and in "Indirect Language and the Voices of Silence" (Merleau-Ponty 1964, 83ff.).

38 "L'initiation" is the term Merleau-Ponty eventually uses to translate Stiftung in The Visible and the Invisible (Merleau-Ponty 1964/1968, 292/243).

${ }^{39}$ See Lawlor.

\section{Works Cited}

Al-Saji, Alia. "A Past Which Has Never Been Present: Bergsonian Dimensions in MerleauPonty." Research in Phenomenology (2008): 41-71.

Barbaras, Renaud. The Being of the Phenomenon: Merleau-Ponty's Ontology. Trans. Leonard Lawlor and Ted Toadvine. Bloomington: Indiana University Press, 2004.

—. "The Turn of Experience: Merleau-Ponty and Bergson" in Merleau-Ponty and the Possibility of Philosophy: Transforming the Tradition. Eds. Bernard Flynn, Wayne J. Fromann, Robert Vallier. Albany: SUNY Press, 2009, 33-60. 
- "Perception and Movement: The End of the Metaphysical Approach" in

Chiasms: Merleau-Ponty's Notion of Flesh. Eds. Fred Evans and Leonard Lawlor. Albany: State University of New York Press, 2000.

Bergson, Henri. Matière et mémoire. Paris: Alcon, 1911.

—.Matter and Memory. Trans. by William Scott Palmer. New York: Zone Books, 1988.

Deleuze, Gilles. Le Bergsonisme. Paris: PUF, 1966.

—. Bergsonism. Trans. Hugh Tomlinson and Barbara Habberjam. New York: Zone Books, 2006.

—. Différence et Repetition. Paris: PUF, 1968.

-. Difference and Repetition. Trans. Paul Patton. New York: Columbia University

Press, 1994. Hodge, Joanna. Derrida on Time. London: Routledge, 2007.

Deleuze, Gilles and Guattari, Felix. A Thousand Plateaus. Trans. Brian Massumi. Minneapolis: University of Minnesota Press, 1987.

Dillon, Martin. Merleau-Ponty's Ontology. Evanston: Northwestern University Press, 1988.

- "The Unconscious: Language and World," in Merleau-Ponty in Contemporary

Perspective. Eds. Burke and van der Veken. The Hague: Kluwer, 1993, 69-83.

Fink, Eugen. "Das Problem der Phänomenologie Edmund Husserls." Revue International de Philosophie. 1 (1938/39): 226-270.

Heidegger, Martin. Sein und Zeit. Halle: M. Niemeyer, 1927.

-. Being and Time. Trans. Macquarrie and Robinson. New York: Harper and Row, 1962.

Husserl, Edmund. Vorlesungen zur Phänomenologie des inneren Zeitbewußtseins. Halle: Max Niemeyer Verlag, 1928.

-. On the Phenomenology of the Consciousness of Internal Time (1893-1917).

Trans. John Barnett Brough. Dordrecht: Kluwer Academic Publishers, 1991.

—. Formale und tranzendentale Logik. Halle: Max Niemeyer Verlag, 1929. 
-. Formal and Transcendental Logic. Trans. Dorion Cairns. The Hague:

Martinus Nijhoff, 1969.

Lawlor, Leonard. "The end of phenomenology: Expressionism in Deleuze and Merleau-Ponty." Continental Philosophy Review 31 (1998): 15-34.

Levinas, Emmanuel. "Ethics as First Philosophy" in The Levinas Reader. Ed. Sean Hand. Cambridge: Blackwell, 1989.

Merleau-Ponty, Maurice. Phénoménologie de la perception. Paris: Gallimard, 1945.

-. Phenomenology of Perception. Trans. Colin Smith. London:

Routledge, 2006.

-. Institution and Passivity: Course Notes from the Collège de France

(1954-1955). Trans. Leonard Lawlor and Heath Massey. Evanston: Northwestern University Press, 2010.

_. Le Visible et l'invisible. Ed. Claude Lefort. Paris: Gallimard, 1964.

- The Visible and the Invisible. Trans. Alphonso Lingis. Evanston:

Northwestern University Press, 1968.

—. L'oeil et l'esprit. Paris : Gallimard, 1964. translated into English as

-. "Eye and Mind" in The Merleau-Ponty Reader. Eds. Lawlor and

Toadvine (Evanston: Northwestern University Press, 2007.

—. Sens et non-sens. Paris: Gallimard, 1996.

—. Sense and Non-sense. Trans. Hubert L. Dreyfus and Patricia Allen Dreyfus. Evanston: Northwestern University Press, 1964.

—. La prose du monde. Ed. Claude Lefort. Paris: Gallimard, 1969.

—. The Prose of the World. Trans. John O'Neill. Evanston: Northwestern University Press, 1981.

—. Signes. Paris: Gallimard, 1960.

—. Signs. Trans. Richard McCleary. Evanston: Northwestern University

Press, 1964.

Sartre, Jean-Paul. L'etre et le néant. Paris: Gallimard 1943. 
—. Being and Nothingness. Trans. Hazel Barnes. New York: Washington Square Press, 1954.

Toadvine, Ted. "Singing the World in a New Key: Merleau-Ponty and the Ontology of Sense." Janus Head (2004): 273-283. 